\title{
The Roots of the Helping Approach towards Man František Burda
}

\begin{abstract}
The study focuses on the topic of service and its identity, while opening up the fundamental question of the nature of the relationship between so-called service identity and the theological and anthropological concept of the human image. Theological principles are elaborated and studied within the framework of the discourse of dogmatic theology. Cultural phenomenological and anthropological facts regarding the metadogmatic need for salvation in the service phenomenon are developed. The revelation of the relationship differences within the Trinity is relevant to the identity of man given the need for the connection of essence with existence and theory with practice. The identity to be one's own self must be concretised. The platform of concrete identity is a specific service practice. The phenomenon of service in culture cannot be perceived only as a cultural segment which concerns only selected individuals, but it must be understood as the basic means within civilisation of the self-realisation of the individual's identity.
\end{abstract}

Keywords: service, theology of culture, cultural and social anthropology, Trinitarian relationship differences, syncatabasis

In general, based on observations and historical sources, we can say that all cultures contain certain forms of solidarity. However, it does not explain to us the existence and enormous development of the element of service in European culture. A wider and more developed system of solidarity and structural assistance (which is a predecessor of service) appears in the historical scene for the first time with the Old Testament Jews. However, the manifestations of this solidarity are provided only within the ethnic community of the Jewish nation. The situation is radically transformed with the coming of Christianity. The radical change (which is associated with it) is the conceptualisation of each person as neighbour. ${ }^{1}$ This change was also an unacceptable cultural shock even for the immediate followers of Jesus. Gradually, but relentlessly, it initiates the process of interactive behaviour that produces a social system (functioning then again as a model for subsequent interactive behaviour). We can talk about the cultural integration (attributed with logic and meaning) of collective consciousness ${ }^{2}$ and about the integration attributed with causality and function that creates causal networks and shapes the social system. ${ }^{3}$ Religious experience

Cf. Nikolaj BERĎAJEV, Filosofie svobodného života II., Červený Kostelec: Pavel Mervart, 2009, p. 56.

Cf. Maurice HALBWACHS, Kolektivní pamět', Praha: Slon, 2009, pp. $26 \mathrm{ff}$.

Cf. Clifford GEERTZ, Interpretace kultur. Vybrané eseje, Praha: Slon, 2000, p. 168. 
thus becomes the basis for cultural experience, and in turn (through the cultural experience) the 'unspeakable - transcendental' gains the ability to be reflected and institutionalised in the symbolic structures of culture and standards of behaviour. Such a cultural change is the practical and intentional influence of the person and the story of Jesus Christ. Jesus' pneumatic-paracletic and mimetic presence in the Church has consequences not only for the life of the Christian community but also for the life of society as a whole. The practice of following this paradigm shift requires a permanent change of mind (metanoia), which can never be replaced by mere institutional affiliation. The biblical conception of both God and man, especially in the New Testament form, is essentially associated with 'the practice of people which frees their neighbours. ${ }^{4}$ Universalised, and therefore secularisable values are released from the Christian tradition of experience for the benefit of all people and become a part of cultural experience that is passed on continually. Secularity, in closer analysis, constantly points to the source and foundation, and inspiration and orientation from which and through which it emerges. ${ }^{5}$

What is the basis for deepening or even changing the conceptualisation of a person in which the way for service becomes open? From what image of man does the service phenomenon come from? In the background of the phenomenon of the service is the Christian concept of man as a person. This concept of man is formed on the basis of the fact that he or she is created. Man is created as the image and form of God. On one hand, he or she is endowed with free will and reason - the more one is free and the better he or she uses his or her mind, the more he or she is him or herself - and, on the other hand, the human being is limited but capable of transcendence and self-transcendence. That gives him or her the ability of openness, receptivity and gifting, and self-sharing. ${ }^{6}$

The more he or she receives and the more he or she gives, the more he or she becomes him or herself. Both principles of free will / reason and receptivity / self-sharing are complementary to each other and do not deny themselves; on the contrary, they function in mutual dialogue.

But where does man gain such knowledge? There are facts to which man has no access (due to the limits of reason) and to which (on the other hand) reason is brought on the basis of cultural dialogue with Revelation, ${ }^{7}$ on the basis of the human ability of self-transcendence. From Revelation, for example, he or she learns that a human individual is the image and form of God. The dialogue of both principles (reason and belief in the revealing truth) is then reflected in the conscience that is natural for man, but at the same time it transcends him or her. ${ }^{8}$ Respectively, it leads him or her to transcend him or herself. In the conscience, the individual opens him or herself to the 'sense' or to the 'truth' of the dialogue. ${ }^{9}$ In conscience, man, his or her intellect and his or her will, becomes penetrable for sense, grace, or truth, which he or she does not own. The answer to the dialogue within the conscience is not 'possessing' or usurping the truth. It is rather responsibility for the known truth, which is manifested in the service to truth or the diakonia of truth. ${ }^{10}$

'Man essentially find him or herself in the dialogue." ${ }^{11}$ The intensity of the internal dialogue is then

4 Cf. Edward SCHILLEBEECKX, Lidé jako Boží př́iběh, Brno: CDK, 2008, p. 196.

5 Cf. ibid., p. 262; cf. also Francis FUKUYAMA, Konec dějin a poslední člověk, Praha: Rybka Publishers, 2002, pp. 72, 195f; Umberto GALIMBERTI, Psiche e techne. L'uomo nell'età della tecnica, Milano: Feltrinelli, 1999, p. 289f; Tomáš PETRÁČEK, Adaptace, rezistence, rezignace. Církev, společnost a změna v novověkých dějinách, Ostrava, Moravapress, 2013, p. 80.

6 Cf. Norris W. CLARKE, Osoba a bytí, Praha: Karmelitánské nakladatelství and Krystal OP, 2007, p. 81.

7 Respectively with the historical form of Revelation, which is codified in the Scriptures and Tradition.

8 Cf. Jiří KABELE, Přerody. Principy sociálního konstruování, Praha: Karolinum, 1998, p. 78.

9 Cf. Emerich CORETH, Co je člověk?, Praha: Zvon, 1996, pp. 183-186.

10 Cf. Ctirad Václav POSPÍŠIL, Teologie služby, Kostelní Vydř́i: Karmelitánské nakladatelství, 2002, p. 19.

11 Romano GUARDINI, Svět a osoba, Svitavy: Trinitas, 2005, p. 115. 
projected externally, into our acting and above all into our mutual relationships. The inner dialogue principle reveals the fundamental focus of man on another person. Man is fully realising his or her receptivity and self-sharing in the concrete love of the equal 'me/you' relationship. ${ }^{12}$ The expression of love's concretisation is then a helping practice, a concrete relationship of communication between two entities, in which a creative effort of becoming less selfish, and the desire to be empathic and to be able to understand takes place. This is only possible on the ground plan for the meeting of a functional and penetrable conscience of one person with the trust of the other person.

Man is at the same time portrayed as one who creatively changes him or herself by means of efforts to reconcile action and thought, theory and practice, truth and love. This characteristic is derived from the interconnection of divine and human nature in the person of Jesus Christ and from the integral unity of Christ's practice with his teaching. Based on the hermeneutic relationship of these factors, it is clear that one cannot own the truth but can be true if his or her truth spreads love and lives from love, and at the same time when his or her love lives from the truth and spreads the truth. The dividing of theory and practice, doctrine and action, is merely an abstraction. The truth of man's existence requires a helping and unselfish attitude towards the other, and at the same time the acceptance of the other in his or her truth.

An important sign (from which the concept of a person who activates the cultural phenomenon of service is based on) is the syncatabitic or kenotic nature of God's identity. God kindly brings himself closer to creation, to man, in the incarnation of God in history, self-denial, the limitation of his own omnipotent power, the acceptance of human pain, suffering and death in the human body, and in human mortal weakness - these create the prerequisite for ethics of participation, cohabitation, consensus, and dialogue. ${ }^{13}$ The God of the biblical message is radically on the side of the sufferer, on the victim's side (which he always reveals as innocent). ${ }^{14}$ 'God's disapproval with the sacrifice is an important anthropological sign. ${ }^{15}$ Divine authority stands on the side of the weak, handicapped, persecuted, condemned, ill, socially displaced, simply on the victim's side. God shows such a deep compassion for the victim that he even stands in his or her place - he himself becomes a victim. The biblical concept has led man (for centuries and through culture) to a greater sensitivity of the heart. That has caused, firstly, that one could see what he or she previously did not see or did not perceive, and, secondly, that he or she could be interested in things he or she was not interested in before. The sensitivity of the heart is deeply biblical in character and deeply human in character. European humanism is the genealogical branch of biblical humanism. ${ }^{16}$ God, in the person of Jesus Christ, is becoming a figure of imitation that influences the cultural dynamics of figuration, semiotisation, and biography of cultural and social events. ${ }^{17} \mathrm{Christ}$ 's coming out of himself (syncatabasis, the lowering of himself) is a prototype of a perfect openness, of a coming out of oneself towards another person and his or her situation. This syncatabasis without reservation opens the perimeter of love for the benefit of all human individuals. ${ }^{18}$ It is

12 Cf. ibid., pp. 96, $118 \mathrm{f}$.

13 Gianni VATTIMO, Pier Aldo ROVATTI, Pensiero debole, Milan: Feltrinelli, 1983, p. 82.

14 The Gospels reveal the fact that anger and hatred come into the heart of man and will poison him or her (even though he or she feels that he or she is fighting evil). 'The struggle with evil can easily change into committing evil ... hatred towards the bearers of evil is often only a manifestation of our selfishness.' Cf. Nikolaj BERĎAJEV, Filosofie svobodného života I., Červený Kostelec: Pavel Mervart, 2009, pp. 228, 245.

15 Michael KIRWAN, René Girard. Uvedení do díla, Brno: CDK, 2008, p. 82. Cf. also ibid. pp. 81-89.

16 Cf. POSPÍŠIL, Teologie..., p. 16; Erich FROMM, Umění milovat, Praha: Orbis, 1967.

17 Cf. KABELE, Přerody..., pp. 42-67, 91-129, 157-199.

18 Cf. POSPÍŠIL, Teologie..., p. 62. 
a distinctive model in which the level of 'thinking' is fully concretised in the specific form of the serving 'attitude. The challenge of imitating such an act (the lowering of oneself) therefore has two inseparable levels: imitation of mind and imitation of behaviour. The syncatabasis rests on three pillars: 1) leading out from slavery/misery, suffering, sickness, anxiety, paralysis and fear, and bringing into freedom; 2) listening to and accepting the world of the one who is the object of the lowering of ourselves - we lower ourselves to the way he or she perceives, experiences and reflects, into his or her inner world; and 3) coming out of oneself, abandoning own origins, imagination, power, superiority, self-confidence, feeling that something is below our level.

Another anthropological feature behind the phenomenon of serving is the concept of a person in dynamic tension between the image and the form of God. Man is perceived as the one who is already what he or she is, and, at the same time, as one who is becoming what he or she is. Anthropologically, we can also understand this dynamism as the dynamics of the pati/agere. Man is defined as both passive receptivity and active creativity. ${ }^{19}$ The privileged place of God's image in man is his or her soul, his or her heart. Here the decisive struggle for human identity takes place. Depending on what one brings to the heart in the first place, he or she also acts and realises him or herself. What he or she loves (what he or she puts in the first place in his or her heart) is that which shapes and transforms him or her and that symbolically becomes his or her God. What he or she loves literally controls and influences his or her thoughts and actions, and also influences how he or she treats his or her own identity. ${ }^{20}$ Thus man always lives and realises a certain form of spirituality, because his or her actions, and he himself or she herself, are always created according to the 'God' he or she carries in his or her heart in the first place, and to whose absolute authority he or she listens to.

Man understood as the image of God is the foundation for the unity of all people in the unmistakable, indisputable, inalienable dignity (which cannot be passed on), and uniqueness of the individual. A person who, in consciousness, realises that even if all people have the same dignity, it is still denied to some of them, or it is taken from them by someone or something, feels a call to action. For this reason, he or she comes to the weakest, the most condemned, the most abandoned, and to the ones who suffer the most. The main means of self-realisation of an individual becomes the answer to one's own conscience, which is called by grace to serve in favour of human dignity. But biblical anthropology also reveals man as a being constantly subject to deceit and false transcendence. It shows him or her as the one who constantly puts false gods in his or her heart, leading him or her to selfishness, violence, abuse or even the killing of others. False images of human identity draw one into a spiral of pain, injustice, indignation, dissatisfaction, anger and resentment, harm to others and to oneself, misunderstanding, mismatch, a feeling of anxiety, frustration, restlessness, feelings of emptiness, manifestations of selfishness, indifference, humiliation and humiliation of others, distrust, vanity, and the desire to control, manipulate, etc. Man has an almost inexhaustible ability to deceive him or herself.

If the biblical God is substantially defined by the coming out of himself, ${ }^{21}$ by approaching Creation and man, then the factor of coming out of oneself is also related to the identity of man. ${ }^{22}$ The egoism of man, on the contrary, grows away from his or her own identity. Coming out of him or

19 Cf. František BURDA, Obraz člověka ve filosofickém světě Karola Wojtyly, Ústí nad Orlicí: Oftis, 2011, pp. 147-155; cf. also CLARKE, Osoba..., pp. 88-98.

20 Cf. POSPÍŠIL, Teologie..., p. 50.

21 Cf. Ctirad Václav POSPÍŠIL, Jako v nebi, tak i na zemi. Náčrt trinitární teologie, Kostelní Vydří: Karmelitánské nakladatelství - Krystal OP, 2007, pp. 358f.

22 Cf. Martin VAŠEK, Aurelius Augustinus. O vôli, milosti a predurčení, Bratislava: Iris, 2007, p. 79. 
herself (in its concretised form) takes place in service relationships which are filled with sensitivity for others and their needs. On the other hand, insensitivity to others and their needs in relationships is a form of egoistically aimed behaviour. A fake image becomes a fetish for a person. ${ }^{23}$ It affects his or her thinking and behaviour (often without his or her awareness). It may be power, career, property, glory, success, performance, prestige, physical fitness, sensual perceptions, beauty, etc., or practically anything. Thanks to false images, man gradually ceases to see his or her neighbour in others. On the other hand, the identification and elimination of false images of man frees him or her and opens him or her up for the relationship and gives him or her an impulse towards the practical love of service character. The service enables one to truly see neighbours in the others. Thus, the service does not mean (in the first place) different ways of helping a neighbour, but the service is, foremost, a way and a possibility for any human to be truly him or herself. It is a concrete way to our own identity. The service does not only take place in institutionalised or even professionalised practice; it is a way of fulfilling any interpersonal relationship as well as a way of fulfilling one's own identity.

However, the main anthropological source (from which the service phenomenon draws its specific character) is further related to the inner life within the Holy Trinity. The service is a specific form of relationship. It is derived from the relationship among the divine persons within the Holy Trinity. Man as an entity created according to the image and form of God is created according to the image of the Holy Trinity. Relationships in the Trinity are perceived as pre-images of human relationships. Regarding the difference of the Divine Persons, nothing can be learned from Revelation except the so-called relationship difference within the Trinity.

The individuals of the Trinity are all identical in character. The only difference among them is the fatherhood of the Father, the sonhood of the Son, and the unpredictable passive inhalation and active exhalation of the Holy Spirit - these characteristics cannot be passed on. The interrelationships among them within a single Divinity are defined in the Trinitarian plan as the Loving One, who is simultaneously the Beloved One $\leftrightarrow$ the Beloved One, who is also the Loving One, and in between them, the inhalation and exhalation of Love flows; the Giver, who is at the same time the One who Receives $\leftrightarrow$ the One who Receives, who is at the same time the Giver, and in between them, the flow of breathing and exhalation of Gift flows; the Speaker who is also the Spoken One $\leftrightarrow$ the Spoken One, who is at the same time the Speaker, and in between them, the inhalation and exhalation of the Sounding Space circulates; the One Able to Relate, who is at the same time the Subject of Relation $\leftrightarrow$ the Subject of Relation who is at the same time the One Able to Relate, and in between them, the inhalation and exhalation of the Relationship circulates. ${ }^{24}$

Man, created in accordance with the image of the Trinity (which is defined by the relationship formulas), therefore becomes him or herself in relationships. The relationships within the Trinity provide us with an important model of the relationship structure. The relationship in which the identity is realised is special and such a process does not occur with all kinds of relationship. The real relationship is only when it is filled with love when it is (at the same time) self-giving and receiving of the other, and (at the same time) when there is space for respect, equivalence, and partnership provided. ${ }^{25}$ If the only element of this equation is absent or inadequate, then such a relationship is incomplete. The measure of incompleteness equals the measure of moving far away from our true identity.

23 Cf. Milan MACHOVEC, Smysl lidské existence, Praha: Akropolis, 2008, p. 55.

24 Cf. POSPÍŠIL, Jako..., pp. $346 f f$.

25 Cf. ibid., p. 493. 
In the image of the Trinity we can see that relations are simultaneously realised both inside and outside (Incarnation). Man is then the one who is an image of God on one side, but at the same time he or she is the one who becomes the form of God on the other side, by concretising his or her own identity externally in service relationships (by concretising love, relationship, gift, and equivalence). Human identity is thus understood as an identity defined by serving. Service (love, relationship, gift, equivalence) implies coming out of oneself through respect for human dignity, which is accepted as undeniable and given. At the same time, it is conditioned by going out of oneself through realising one's existence in donating and accepting as well. One is also expected to come out of him or herself by realising his or her existence as a loving and loved one. At the same time, one is expected to come out of him or herself in concrete equal relationships.

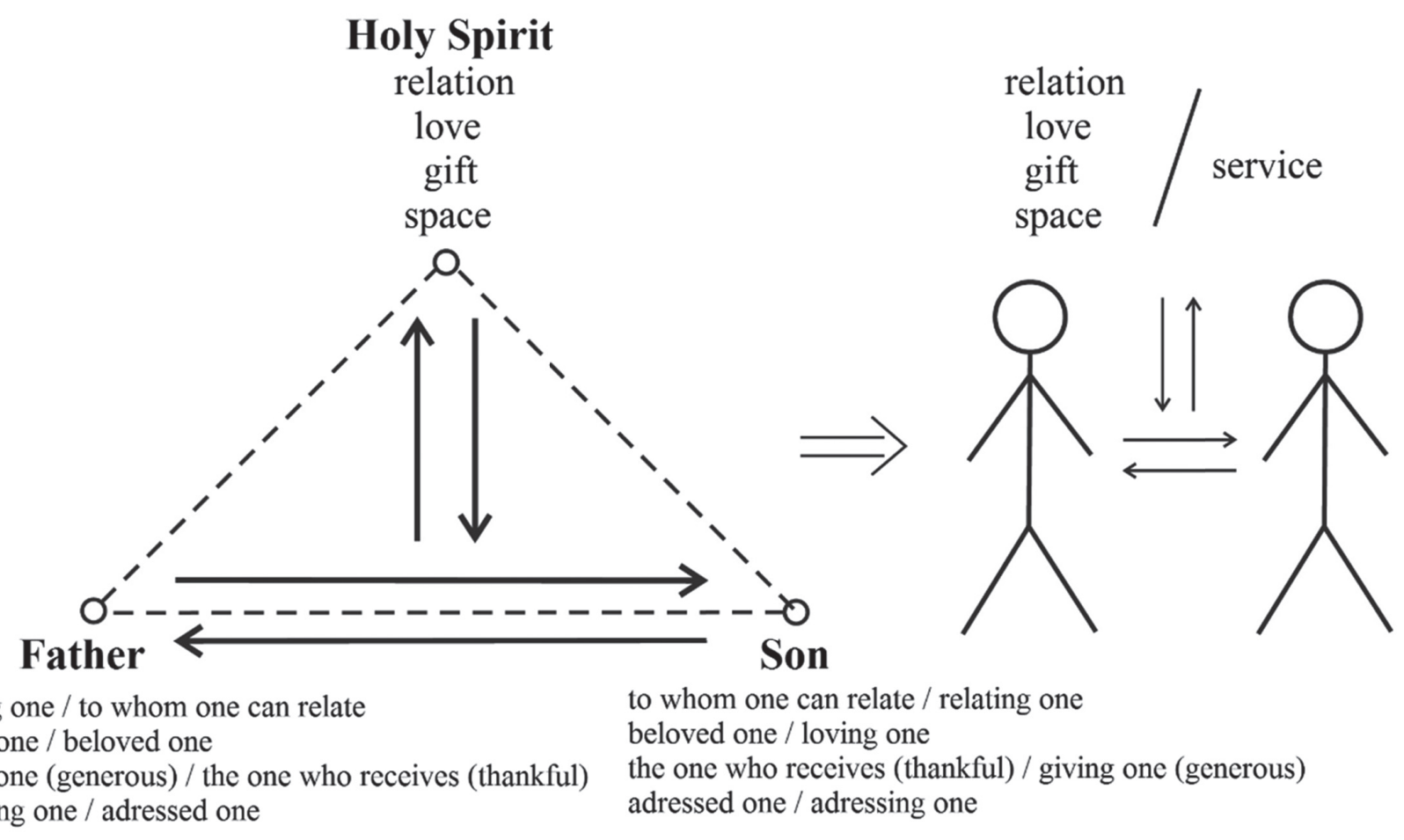

The nature and basis of service practice does not lie in methodology. Methodology is only a tool. The nature and basis of service corresponds to the nature and foundation of human identity. The central human need is the desire to be true to oneself. However, man reveals him or herself as a question and as a task to accomplish. Theological anthropology opens up a perspective in which the path to self-realisation, self-acceptance, and self-actualisation leads through the kenotical coming out of oneself and approaching the other person. The process is concretised on the ground of service relations. We can say that here is the relationship equation identity $\leftrightarrow$ service, which is derived from the concept of man as the image of God. Thus, the service character of human identity is at the same time a consequence of the relation equation Trinity $\leftrightarrow$ identity $\leftrightarrow$ service. In this sense, Christian theology is at the same time anthropology which stands in the background of the cultural integration of the collective consciousness. This kind of consciousness creates the causal network and forms the social system. 
$109 \frac{8}{2018}$

\section{Contact}

ThLic. Petr František Burda, Th.D.

University of Hradec Králové

Faculty of Education, Department of Cultural and Religious Studies

frantisek.burda@uhk.cz 